\title{
The Concept of Choice in Learning and Teaching Composition
}

\author{
JACK BREEN \\ Delft University of Technology \\ The Netherlands
}

\section{INTRODUCTION}

This paper adresses the aspect of Composition in architecture and urban design and focuses on the meaning of choice within the design process. Through the concious generating of visual models of choice and the stimulation of analysis of the ways in which individual design decisions are shaped, a greater insight may be achieved into the understanding of composition and the way in which this aspect may be expressed in individual designs.

\section{DESIGN}

Characteristic of design on an architectural scale is the combination of a variety of influences and facets which together should form a complex, but at the same time complete product: a synthesis in the form of a spatial and material concept. Design: the creative process of simultaneous organisation on different levels, among them twodimensional and three-dimensional; functional, structural and aesthetic, may to a large extent be viewed as an act of Composition.

How should future architectural- and urban designers be made aware of the relationship between visual wholeness and contrast; of the meaning of compositional harmony and tension and the opportunities of these aspects in the design of spatial structures?
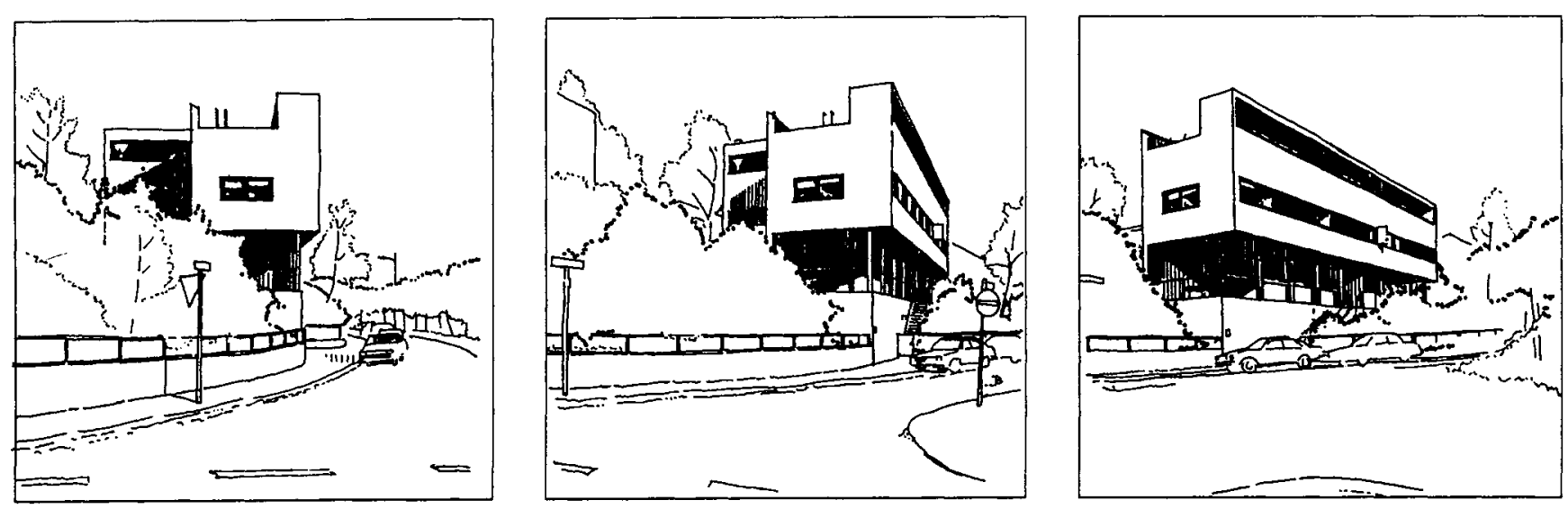

Figure 1. Dynamic perspective: three views of one of Le Corbusier's buildings for the Weissenhofsiedlung, Stuttgart.
Designs - both by professionals and by students - are often judged to a large extent on the basis of the quality of their composition. It may therefore be argued that a significant part of design education courses should be aimed at creating insights into this field.

Fundamental to the ability to create compositions is understanding. One has to acquire cultural and technical knowledge and an understanding of the effects of spatial experience and the perception of visual phenomena. In architectural education an important role is played by the study of precedents. By learning to 'read' visual information one can develop the ability to translate ones own ideas into form. Architectural and urban plans are not created directly 'in situ' but are concieved, notated and communicated via specialized media such as drawings and models.

The process of designing is iterative: one takes a step forward by evaluating, 'testing' the new development within the design process in relation to the previous step(s), weighing whether the new interim result is more appropriate and precise than the previous one or if another course should be followed. The activity in these series of design 'loops' can be characterized as being primarily a process of "imaging" as Zeisel has noted. 'Design decisions are to a very large extent made on the basis of visual impressions.

The drawings we use are abstractions of - real or imagined spatial configurations. Although a designer might for 
instance translate a design concept into a series of drawings: plans, cross-sections and facades, these images are in reality never percieved in such a way.

There is a clear distinction between the way in which for instance a painting, which is a composition in two dimensions that may suggest depth, is experienced and the way in which objects and spaces change visually as they are observed in motion. An effect for which I would like to introduce the term "Dynamic Perspective" (see figure 1). The importance of a less two-dimensional, plan-oriented attitude to the design of cities and of a more 'scenographic' approach has in the past been stressed by authors like Bacon, Lynch and Cullen, who introduced the term "serial vision."

\section{PERCEPTION AN COMPOSITION}

The human being possesses an extremely refined and effective visual perceptive system, as J.J. Gibson noted as early as 1950 (see quote). ${ }^{3}$ Through our eyes we are continually searching, with an obsession for clarity, seeking order and 'reading' our environment; an activity aimed at the 'understanding' of our surroundings.

Peter F. Smith argues that aesthetic perception represents an extension of brain programs relating to adaptation and survival. ${ }^{4}$ Through exploration and interpretation of our surroundings (both natural and those conceived by man) comes the appreciation and articulation which initiates aesthetic experience. This cycle of curiosity and exploration (originally primarily aimed at environmental orientation and recognising danger) leading to a higher state of concious 'orderliness', is said to be at the root of our own aesthetic experience. ${ }^{5}$

Orientation: recognising and understanding where we are in our world has always been an important factor. In the wandering existence of early man this process of recognising, understanding and subsequently transmitting such information to others for 'safekeeping', may well have been communicated and memorized through song. The visual world interpreted as 'serial vision', transformed into (musical) composition (see the excerpt from 'The Songlines'). ${ }^{6}$

The settlement of man stimulated the emergence of drawings: plans and maps, abstractions for the benefit of communication which in turn (as any map-enthousiast knows) can have aesthetic qualities of their own.

We do not experience the visual world around us (either natural landscapes or manmade environments, such as buildings or urban 'cityscapes') as a whole, but rather as a chain of events, each chain taken in one at a time and in relation to the other. It is relevant to consider spatial experience not so much in terms of time and (infinite) space but as the appreciation of place (in the German language the word "Raum", corresponding to 'room'). In the words of Aldo van Eyck: the experience of "place and occasion"?

The aim of designing is the creation of (man-made) surroundings that are functionally and structurally clear and create this sense of 'place', but which should also be visually pleasing, offering a sense of emotional wellbeing. To use an oldfashioned (?) concept: to create beauty.

A building should be more than a sum of design solutions. The elements should be combined economically and creatively to be effective on an aesthetic level. The parts which together make up the whole may be recognisable as such, but should in a successful composition reach a form of synthesis (or perhaps, as Kurokawa suggests, should coexist in a state of symbiosis). ${ }^{8}$

The success or failure of this undertaking in design is a matter of composition: of the treatment of size and proportion, of consistency and contrast, of structure and pattern and the expression of material and colour. These aspects should be integrated into designs in such a way that they may be discovered and appreciated, but (it is my conviction) ought not to dominate. In the words of Peter F. Smith:

The most successful buildings are those which clearly express their elements but which, at the same time, come across as wholes which are much greater than the sum of their parts. This is the primary aesthetic "dialectic" in architecture. Aesthetic success demands that orderliness wins, but not too easily. There has to be sufficient complexity to make the perception of unity a worthwhile mental achievement. ${ }^{9}$

Less need certainly not be more, but too much is definitely too much!

To quote Leon Battista Alberti paraphrasing Vitruvius:

Beauty consists in a rational integration of proportion of all the parts of a building, in such a way that every part has its fixed size and shape, and nothing could be added or taken away without destroying the harmony of the whole. ${ }^{10}$

When designing (particularly in the case of students) the problem is generally not a lack of ideas, but too many ideas. The difficulty of design is often which ideas to choose and develop further and which to jettison (at least for the time being). The process of Composition is one of getting to the heart of the matter: a proces of simultaneous reduction and perfection! This can mean a painstaking search, comparable to a process of hunting (complete with anxiety, hunger, excitement and euphoria).

In the case of the painter Piet Mondriaan (particularly in his later work), this mental and visual search could sometimes take years, until he was satisfied with a work which would be minimal, yet powerful and which in limitation created tension. Mondriaan emphasized the importance of this visual quest, stating: "if we cannot free ourselves, we can free our vision"."

There are clearly parallels between architecture and urban design and with other artforms such as music. Philosophers such as Schopenhauer debated the concept of 'architecture as frozen music'. ${ }^{2}$ This does not truly do either artform justice. There are clearly parallels, such as rhythm, wholeness and contrast, structure and layering but an archi- 
tectural or urban complex may have different "songlines" woven through it, and to travel one of these "architectural routes' in the opposite direction is not like playing the melody backwards. As I have tried to express through the concept of Dynamic Perspective, there are also close parallels to scenography and moviemaking and of course to the game of Chess: if one piece within an ensemble is moved, removed or substituted by another piece we have an entirely different (pro)position (illustrated by the example of the Delft market square).

One of the recurring themes in architectural theory and education is the search for scenarios which may offer a
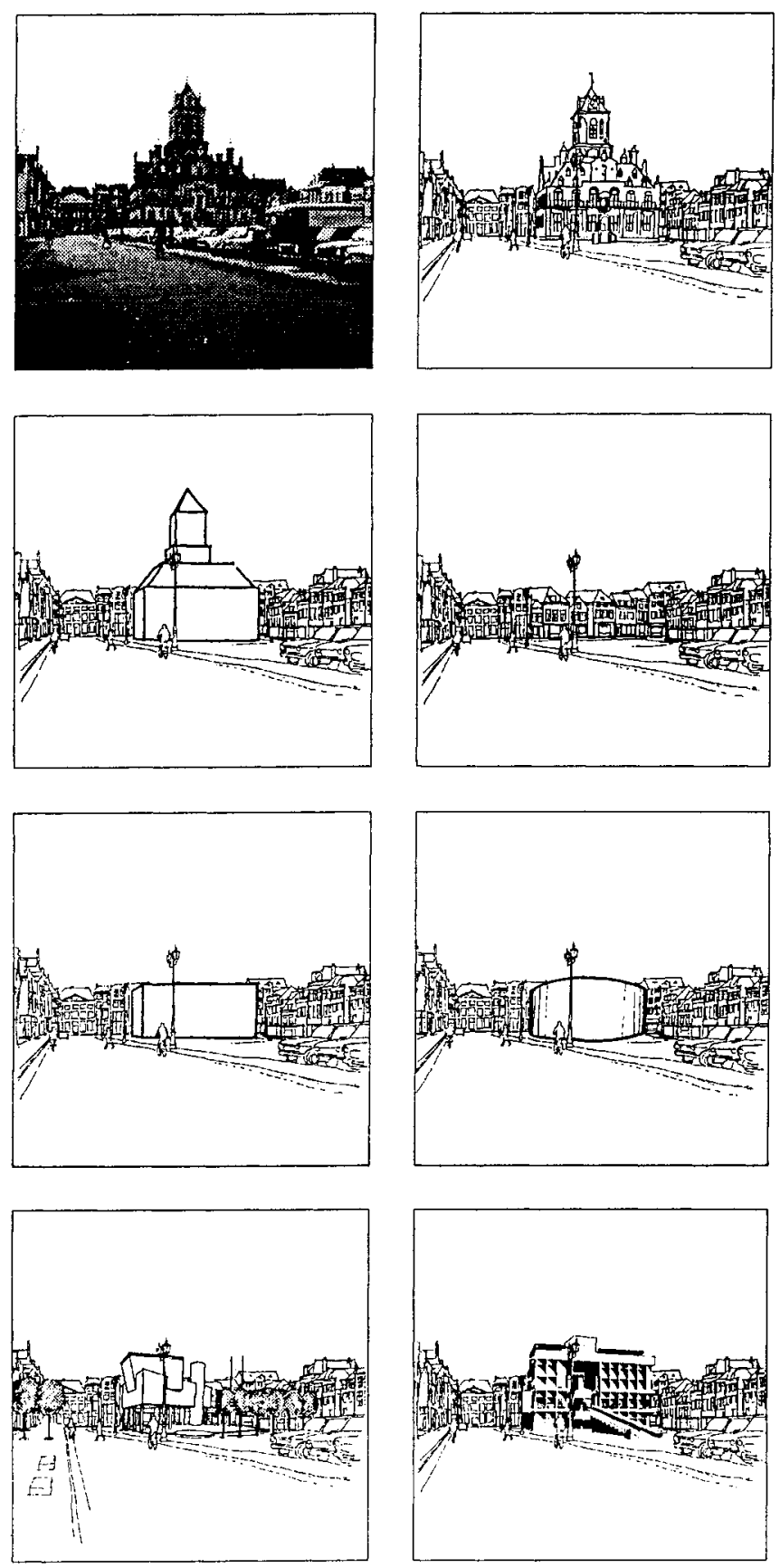

structure to the domain of design choice. Besides the traditional stereotype of the intuitive method of designing and composing, there has been considerable support for a scientific approach to design. The work of J.N.L. Durand is the most prominent to this date, and this methodology is regularly 'rediscovered' and dusted off for present day use..$^{13}$

The more scientific approach generally is based on a systematic arrangement of artefacts by means of typologies. I would like to stress that these are categories distilled from precedents (work that has been realised previously). The aspect of invention, of the 'new', naturally cannot play a part in such a systhematic setup based on historical evidence .
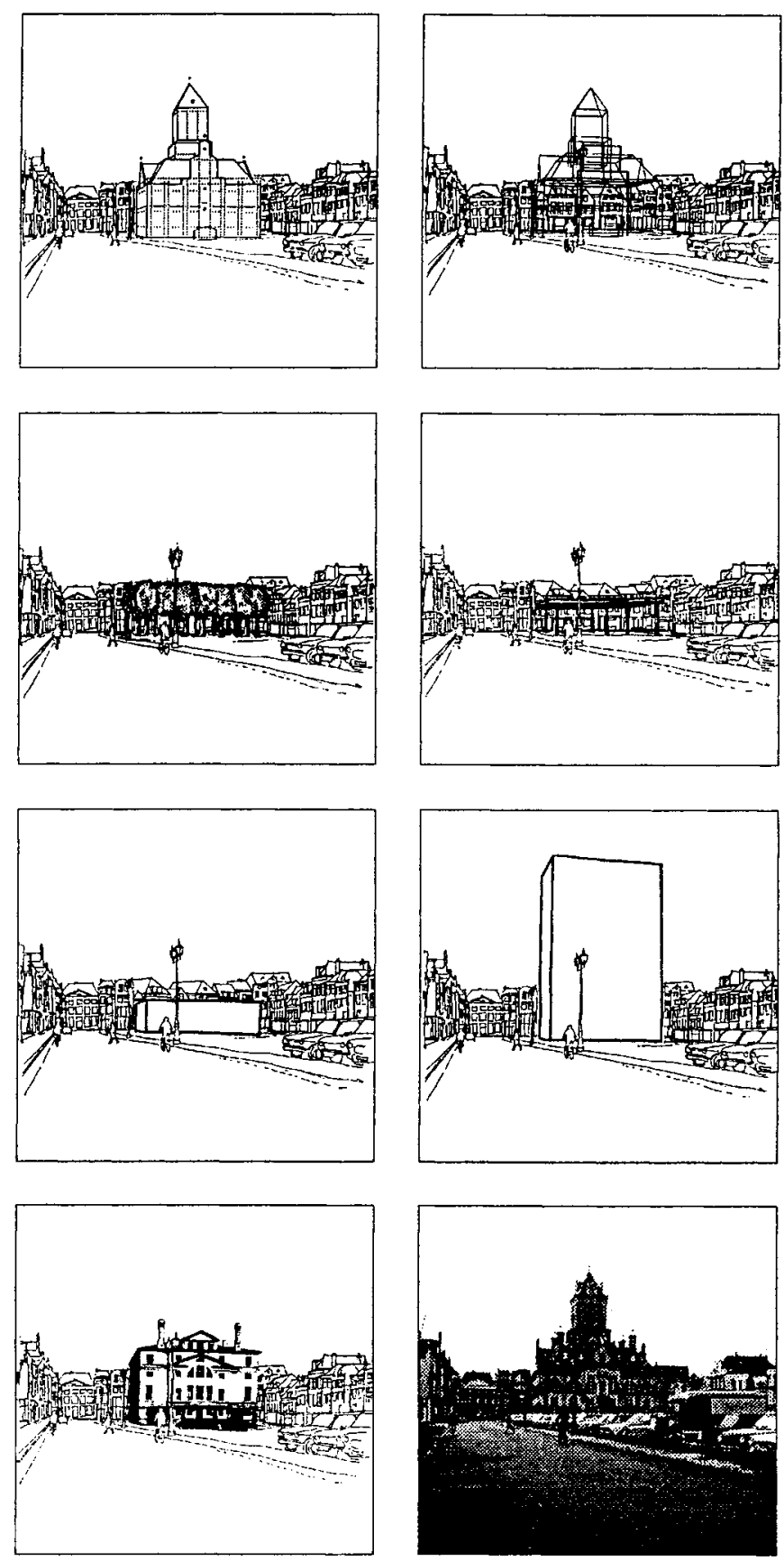

Figure 2. Variations on the theme of the historic market square and townhall of the city of Delft, the Netherlands. 
When working from a typological framework, it is important to realise that these are schemes which are the result of a process of 'filtering' (to a certain extent reductions and abstractions of 'real' designs) and should not be translated directly into built form.

Another way in which compositional themes may be structured is through proportional systems, such as the Golden Section, the Fibonacci sequence and the Modulor. Again, the use of such systems is no quarantee for aesthetic success, and a work which is the result of a more 'intuitive' method may even be more effective, possibly incorporating an element of novelty and surprise (as in the case of Mondriaan).$^{14}$

One of the most effective structuring devices is of course the architectural style. In the Renaissance the renewed orientation on the 'classic' architecture of the Romans and Greeks led to a set of stylistic rules which, when applied by different designers, would not necessarily lead to the same result. They did not form a creative barrier to good architects and in the hands of mediocre or even bad architects might lead to somewhat boring, but never truly atrocious designs. Modern architecture never really produced a 'style' in this sense, but was more a 'movement'; an attitude. Equally the 'Postmodern' movement did not create stylistic clarity, but instead produced a conglommerate of stylistic sub-influences, sometimes inspired by historical themes and sometimes apparantly by high-camp pop culture.
In the present fastmoving, pluriform design-practice there is no universally accepted style, no set of rules!

In the public architectural debate the concept of 'beauty' seems to have faded away into the background (in the Netherlands it appears to have been temporarily replaced by a rather vaque term which may be translated roughly as "image quality"). Nonetheless designers, though sometimes apparantly at a loss, strive towards solutions which are visually interesting and which convey 'meaning' in a cultural sense.

Designing is a process of searching for a correct result. It can be considered 'empirical' only in sofar as it follows a path of trial and error. In designing there is not one correct outcome, but there are many solutions - each offering different (visual) qualities.

It may become clear that there is no standard recipe.

The way in which a designer works when tackling a compositional problem is also influenced by personal preferences, concerning the method and order of working and individual methods of 'imaging'. It would generally be fair to say that the 'scientific' and 'intuitive' methods may be applied side by side (and through each other) when working on design choices. Besides inspiration a large role is played by the analysis of options and the making of choices.

\section{CHOICE}

It is often striking how historians and critics will discuss the
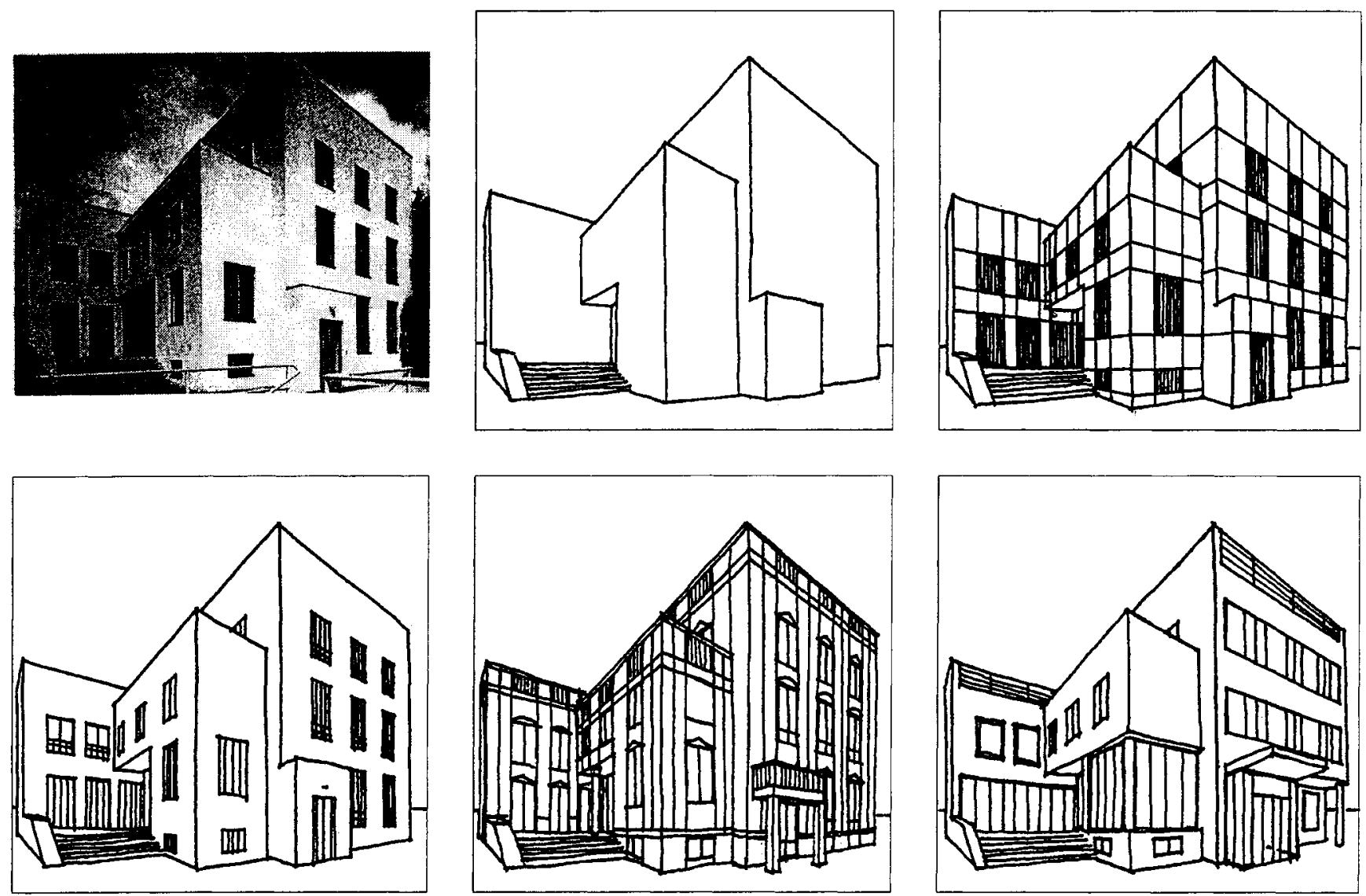

Figure 3. Variations on the basis of Ludwig Wittgenstein's Kundmanngasse house, Vienna, 1929. 
result of a specific design process as something almost inevitable. It seems as if, in retrospect, the outcome had been clear from the beginning of the design process.

It is my considered opinion as a teacher of composition (and as a designer) that this is rarely ever the case (and if it does happen, it may be the effect of lazyness or too much routine on behalf of the designer).

An interesting case is the house which the philosopher Ludwig Wittgenstein built for his sister in Vienna during the interbellum. In a recent book about this house, P. Wijdeveld 15 illustrates a process of "purification" a form of stylistic reduction of the preliminary designs towards a stark "löcher fassade'. This should not be considered a 'natural' process. Had Wittgenstein (who had never built anything in his life before) chosen different design themes (for instance by stressing either vertical or horizontal patterns and infusing stylistic characteristics) a completely different impression would have been the result (see illustration 3 ). We do not fully know to what extent Wittgenstein conciously rejected such options or may not have been fully aware of them.

It is clear that architectural and urban design consist of more than the composition of floorplans and facades. As H.P. Berlage stated in 1908:

The aim of our creations

is the art of space

the essence of architecture. ${ }^{16}$

A large part of the work in design concerns the consideration of the spatial counterform which is the result of the way 'concrete' elements such as walls, roofs and urban blocks are positioned. This is comparable to the way in which the painter George Brague explained how in his cubist paintings he did not just paint the objects, but particularly that which is between the objects (see note) ${ }^{17}$ The concept of that which is between, coupled to perception in motion, emphasises the need to pay attention to the way in which one space is connected to another. In the words of the Dutch so called Forum-group (which come out of Team 10 and included Bakema, Hertzberger and van Eyck) paraphrasing Buber: to create an 'in between realm' (see quote). ${ }^{18}$

Another concept which illustrates the idea of choicemaking is that of Aldo van Eyck's: 'Twin Phenomena' ${ }^{19}$ Van Eyck argues that the phenomena that are a part of the world created through design should not be considered as polar (opposed) aspects but as 'ambivalent', linked realities. One cannot exist without the other. When considering options such as large and small, high and low, light and dark, open and closed, the decision is not a matter of this or that, but of the degree: the correct combination (and 'dosage') of the different aspects.

For the perception and appreciation of design concepts it is of paramount importance how different formal themes are combined in order to achieve a composition: a 'balancing act' incorporating consistency and contrast, clarity and complexity, harmony and tension...

Given the fact that there is no single, correct outcome, how should composition be taught at Schools of Architecture? It is my conviction that understanding can best be reached via the concept of choice. It must be made clear that a variety of solutions is possible, though some are more original and better balanced than others. The comparison and analysis of student work may stimulate curiosity, enthousiasm and insight (both into the ways in which compositions can be appreciated and into personal preferences and weaknesses). An aesthetic experience is a discovery, and the awareness that one has seen and felt this is in itself the 'reward'. In the same way education in this field should stimulate discovery through evaluation of the students' own work and that of others.

A strategy of pluralism can be a useful method for counselling: placing emphasis on different options, preferably several (sometimes even absurd ones) to make the student aware of different stategies, rather than forwarding or suggesting singular solutions (which may be interpreted as being the way the teacher wants to have things done). Besides active, individual counselling and group discussion it is worthwhile to exhibit selections of (successful and varied) student results to stimulate an understanding of ways in which compositional balance may be reached from different points of departure.

\section{THE DELFT FORMSTUDIES CURRICULUM}

The approach to the elementary study of Form and Composition at the Faculty of Architecture at Delft University of Technology ("TU Delff"), could be described as metaphoric, in the sense that the tasks reflect on recurring themes in more complex design projects; but are approached in a more abstract way than in the general programme. The tasks devised by the staff of the Formstudies section are conciously reduced in order to focus on the themes of Composition and Choice. Functional aspects, which normally are stressed in the architectural programme at Delft are minimalized. The emphasis is on the study of form and space, ways of manipulating these, and how the resulting effects are percieved.

Metaphoric in this sense does not imply the use of metaphors as such, aimed at 'freeing' the imagination of students as propagated by Coyne, Snodgrass and Martin. ${ }^{20}$ Metaphors can often be translated too literally; our aim is to stimulate an atmosphere of concentration through abstraction with undertones of reality. The students work threedimensionally. The results are subsequently noted down and analysed on paper.

The most important themes of the Formstudies curriculum:

- Composition: two- and three-dimensional compositiontechniques, shape and gestalt, wholeness and contrast, complexity and reduction;

- Spatial effect and Plasticity: expressive qualities of-, and relationships between volumes (three-dimensional objects) and space (place), form and counterform; 
- Context: the relationship of objects to their surroundings, dynamic perspective, site;

- Size and scale: the relation between form, proportion and the human scale;

- Material expression and colour: characteristics, expressive qualities and methods of use of materials (shape, texture, structure, colour, play of light), techniques and detailing.

In the Formstudies curriculum at Delft these themes form more or less autonomous subjects of study.

The first year is primarily meant as an 'eye opener'. In each of the six periods there is a short (one half day), but intensive working session, in some cases preceded by a lecture and in each case followed by 'homework' (the registration and translation of the model into two dimensional representations). The results of these sessions are documented in an individual portfolio, which gradually grows thicker through the year. In order to reach a relevant result in such a short time serious attention has been given to the definition and clarification of the tasks and to preparing 'sets' of material with which the students embark on their compositional 'excursions'.

The exercises in the subsequent years are longer (up to six half days), but are characterised by a similar compactness and urgency. The aim is for students to individually discover opportunities for composition, within a framework that does not curb creativity or invention but that stimulates comparison.

In order to get an overview of the curriculum it is necessary to understand that the faculty programme consists of five years devided approximately into:

- Two basic years aimed at acquiring knowledge and orientation, with six thematic 'blocks' per year;

- Two more specific years in which the student has chosen for one of five main subjects and

- One year consisting of choice subjects and the final project.

In the following table the first title mentioned is the theme perblock or module and the second the title of the Formstudies exercise which reflects on this general theme.

First year:

- Block 1 - Space Space and Boundary

- Block 2 - Building Process Space, Proportion and Contrast

- Block 3 - The City Urban Space: Form and Counterform

- Block 4 - Building and Construction Structure and Detail

- Block 5 - Facilities Interior Space: Form and Counterform

- Block 6 - Regional Planning Pattern, Concentration and Direction Second year:

- Block 12 - Concept and materialization The Table/The Bench/... as a metaphor for Architecture ${ }^{21}$
Third/fourth/fifth years:

- Module A1 - Architectural Studies

Triad: Coherence and Contrast: 2D/3D/Material Expression

- Module A2 - Concept and Detail Material, proportion and connection

- Module D11 - Media and presentation Shaping the concept and its image

\section{SOME EXAMPLES}

\section{Block 1 and 2}

The theme in the first Block focuses on the possibility to create space(s) by strategic organisation of planes. Nine elements of different propotions are given. In Block 2 one of the models made earlier by one of the students has been selected and scaled down. This model is analysed by the students and translated from this starting point. Students may alter the given spatial configuration, vary the thicknesses of the different planes and introduce a material articulation using a set palette of white, greys and black tones plus material with a linear structure. (see illustration 4)

\section{Block 3}

The theme is the understanding of organised, urban space: "the architecture of the city". Starting from a given, abstract model scale 1:200 the students have to introduce primary elements (a given amount of 'building' volume) plus secondary elements, (such as different levels, patterns, trees and streetlights, suggested by very simple materials). Each student works within an imaginary square, on a cardboard underground which is subsequently removed, so that the basic models can be used by following groups (see illustrations 5 and 6)

\section{Block 4}

The exercise focusses on spatial structures composed of different types of components, with the emphasis on the relationships between the parts within the whole and the aspect of detailing. The starting material consists of five wooden rods, five cardboard planes and five volumes; there is a systhematic buildup in the measurements. Similar to Block 1, the task is to create a composition which is equally

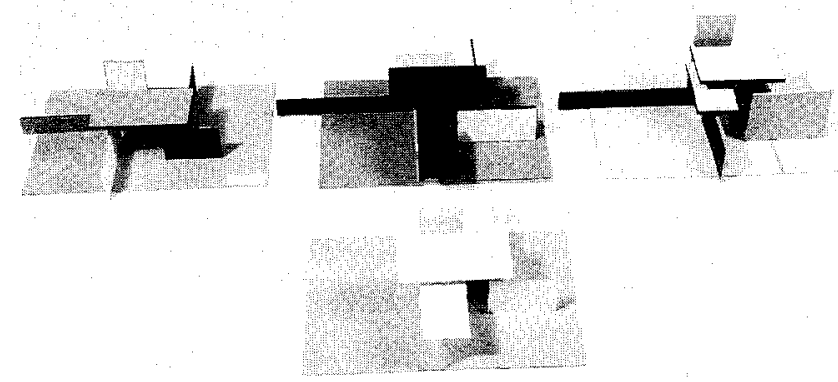

Illustration 4. Block 2: Reference model (front) and three student interpretations. 

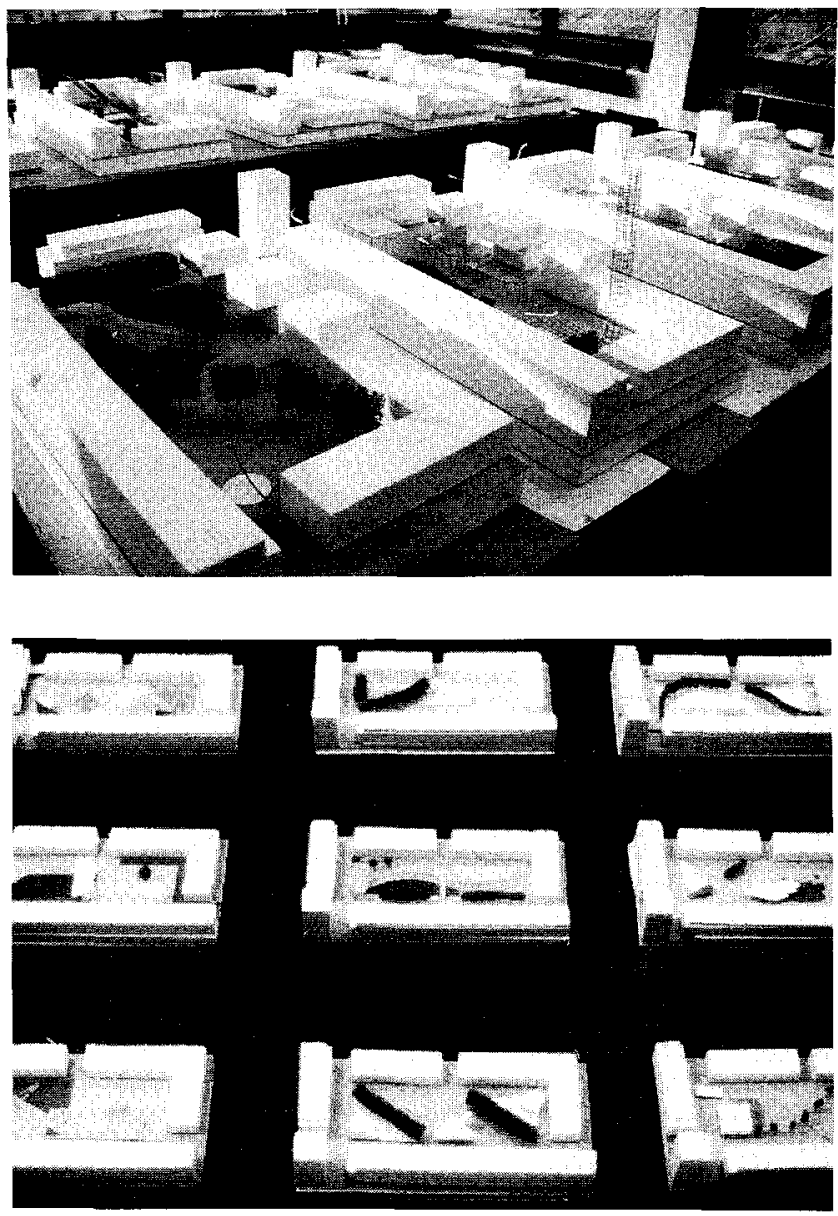

Illustrations 5 and 6 . Overviews of different student stategies for the same (fictitious) urban square.

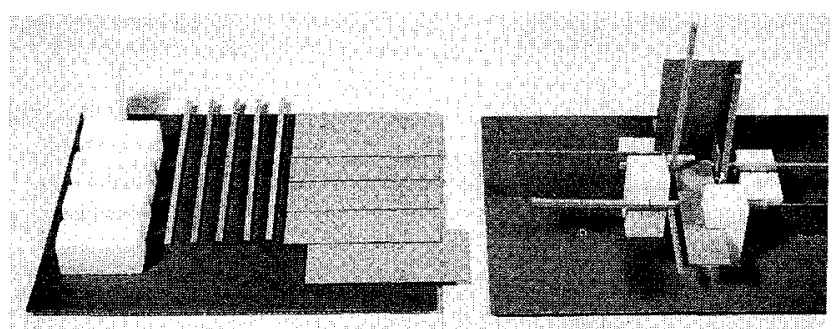

Illustration 7. Starting material and an example of a student model from Block 4.

interesting (though not the same) from all sides. Compared to the 'informal' way in which the models in the first Block are put together, the results in this period acquire a certain precision (see illustration 7).

\section{A1-Module}

The exercise in the A1-module - the Triad - spans six sessions and is divided into three consecutive steps:

- a two-dimensional model using a collage technique, working with black strips of paper on grey undergrounds with different regular patterns (frequently different $2 \mathrm{D}$ studies are made in the first phase);
- an abstract, white, three-dimensional model which is a spatial transformation of the first step;

- a last, materialised version in which the student experiments with the influence of colour, texture, structure, grids etc.

It is particularly interesting to be able to retrace the steps through the models and recognise which choices were made and what the effects were per phase in relation to the final model (see illustration 8).

\section{CONCLUSIONS}

An awareness of the meaning of Composition within design can, and must be taught at Schools of Architecture. As there is no generally accepted mode of composition which can be learnt as undisputed fact, and Design as such consists largely of a process of trial and error, other methods have to be found which can lead to understanding and will stimulate further exploration.

A good pedagogical method may be to dwell on the concept of Choice, through clearly defined exercises that facilitate comparison and analysis, furthering compositional awareness.

The task for future generations of designers will be to create new geographies; not so much of power, but of place and being: to create geographies for experience!

In order to be able to create, it is necessary to discover the relationship between Design and Composition and to study the results of different design-stuggles (both one's own and those of others).

Through the appreciation of what a design could also have been, but (through concious choice) did not, we can create a better understanding of what it has become and why.

\section{NOTES AND REFERENCES}

1 J. Zeisel: Inquiry by Design: Tools for Environment - Behaviour Research, Cambridge University Press, 1984.

${ }^{2}$ G. Cullen: Townscape, The Architectural Press, London, 1961.

$3 \mathrm{~J} . \mathrm{J}$. Gibson in The Perception of the Visual World, The Riverside Press, Cambridge, Massachusetts, 1950:

"All these problems can really be summed up in a single general question: How do we get the experience of a concrete visual world? The visual world can be described in many ways, but its most fundamental properties seem to be these: it is extended in distance and modelled in depth; it is upright, stable, and without
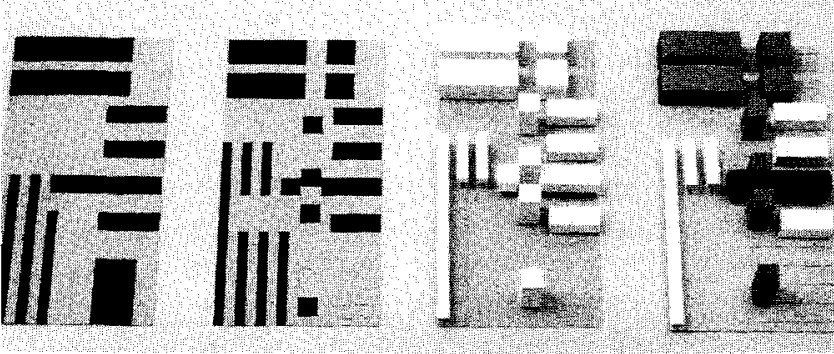

Illustration 8. A1-module: development of a series of compositions from 2D, to 3D, to articulated, materialised concept. 
boundaries; it is colored, shadowed, illuminated, and textured; it is composed of surfaces, edges, shapes, and interspaces; finally, and most important of all, it is filled with things which have meaning. If we could account for the perception of these properties of the visual world, we should at least be well on the way to explaining the whole panorama of visual experience".

${ }^{4}$ P.F. Smith in Etnoscapes: Volume 1; Environmental Perspectives, D. Carter (ed.), Avebury, Aldershot, 1988.

5 P.F. Smith: The Dynamics of Urbanism, Hutchingson, London, 1974.

${ }^{6}$ B. Chatwin in the Novel The Songlines, Viking Penguin, New York, 1987:

...."Most tribes, Arkady went on, spoke the language of their immediate neighbour, so the difficulties of communication across a frontier did not exist. The mystery was how a man of Tribe A, living up one end of a Songline, could hear a few bars sung by Tribe $Q$ and, without knowing a word of Q's language, would know exactly what land was being sung. 'Christ!' I said. 'Are you telling me that Old Alan here would know the songs for a country a thousand miles away?' 'Most likely'. 'Without ever having been there?' 'Yes' ......

'How the hell's it done?'

No one, he said, could be sure. There were people who argued for telepathy. Aboriginals themselves told stories of their songmen whizzing up and down the line in trance. But there was another, more astonishing possibility.

Regardless of the words, it seems the melodic contour of the song describes the nature of the land over which the song passes. So, if the Lizard Man were dragging his heels across the saltpans of Lake Eyre, you could expect a succession of long flats, like Chopin's 'Funeral March'. If he were skipping up and down the MacDonnell escarpments, you'd have a series of arpeggios and glissandos, like Liszt's 'Hungarian Rhapsodies'. Certain phrases, certain combinations of musical notes, are thought to describe the action of the Ancestor's feet. One phrase would say, 'Salt-pan'; another 'Creek-bed', 'Spinifex', 'Sandhill', 'Mulga-scrub', Rock-face' and so forth. An expert songman, by listening to their order of succession, would count how many times his hero crossed a river, or scaled a ridge - and be able to calculate where, and how far along, a Songline he was.

'He'd be able', said Arkady 'to hear a few bars and say, "This is Middle Bore" or "that is Oodnadatta" - where the Ancestor did $\mathrm{X}$ or $\mathrm{Y}$ or $\mathrm{Z}$.'

'So a musical phrase', I said, 'is a map reference?'

'Music', said Arkady, 'is a memory bank for finding one's way about the world.'......"

7 A.E. van Eyck in: F. Strauven: Aldo van Eyck, relativiteit en verbeelding, Meulenhof, Amsterdam, 1994.

${ }^{8}$ K. Kurokawa: Intercultural Architecture, the Philosophy of Symbiosis, Academy, London, 1991.

${ }^{9}$ P.F. Smith in Etnosapes: Volume 1; Environmental Perspectives, D. Canter (ed.), Avebury, Aldershot, 1988.

${ }^{10}$ R. Wittkower: Architectural Principes in the Age of Humanism, Tiranti, 1952: pg. 6.
1 Piet Mondriaan: Toward the true vision of reality, New York (Valentine Gallery), 1942 (exhibition Gemeentemuseum, The Hague, 1995).

12 A. Schopenhauer in: Die Welt als Wille und Vorstellung, Zweiter Band, Zweiter Teilband, Diogenes, Zürich, 1977:

....'Das bloße Gefühl dieser Analogie hat das in den letzten 30 Jahren oft wiederholte kecke Witzwort hervorgerufen, daß Architektur gefrorene Musik sei. Der Ursprung desselben ist aufGoethe zurückzuführen, da er, nach Eckermanns Gesprächen, Bd.II, S. 88, gesagt hat: "Ich habe unter meinen Papieren ein Blatt gefunden, wo ich die Baukunst eine erstarte Musik nenne: und wirklich hat es etwas: die Stimmung, die von der Baukunst ausgeht, kommt dem Effekt der Musik nahe". Wahrscheinlich hat er viel früher jenes Witzwort in der Konversation fallen lassen, wo es denn bekanntlich nie an Leuten gefehlt hat, die was er so fallen ließ auflasen, um nachher damit geschmückt einher zu gehn".

13 Two recent, interesting examples:

W.J. Mitchel: The logic of architecture. Design computation and cognition, MIT Press, Cambridge, Massachusetts, 1990; and L. Madrazo: Durand and the Science of Architecture, Journal of Architecture Education, ACSA, 1994.

14 Contrary to popular belief, in his later work Mondriaan did not work following proportional systems, while his contemporary Marlowe Moss did. I have recently heard the work of these two artists compared by a colleague as "listening to Jazz (Mondriaan) and listening to Western marching music (Moss).

${ }^{15}$ P. Wijdeveld: Ludwig Wittgenstein, Architect, Thames and Hudson, London 1993.

${ }^{16}$ Quote in: C. van der Ven: Space in Architecture, van Gorkum, Assen, 1978.

17 Georges Braque:

"It is difficult to see the things in the painting seperately. There are people who say "what does your painting depict? There is an apple, that I see, there is also... I'm not quite sure... Oh yes, a plate next to it'. It appears to me that these people have completely forgotten that that which is between the apple and the plate is also painted. And I for one find it equally difficult to paint 'what is between the things'. This - between two things - appears to me just as important an element as what they call the object. It is the relationship between the objects and of the object to - that what is between - that forms the subject". (Translation by the author)

From: Forum 14 (NL) (1959) nr. 7.

${ }^{18}$ M. Buber: "Kunst.... ist Werk und Zeugnis der BeBiehung zwischen der substantia humana und der substantia verum - das Gestalt gewordene Zwischen".

F. Strauven: Aldo van Eyck, relativiteit en verbeelding, Meulenhof, Amsterdam, 1994.

${ }_{19}$ A.E. van Eyck: Niet om het even ... wel evenwaardig, van Gennep, Amsterdam, 1982.

${ }^{20}$ R. Coyne, A. Snodgrass and D. Martin: Metaphors in the Design Studio, Journal of Architectural Education, ACSA, nov. 1994.

${ }_{21} \mathrm{~J}$. Breen and B. Olsthoorn: De Tafel als metafoor voor architectuur, Publicatieburo Bouwkunde, TU Delft, 1993. 